Academic Voices

A Multidisciplinary Journal

Volume 6, No. 1, 2016

ISSN 2091-1106

\title{
LOAN MANAGEMENT OF NABIL BANK AND EVEREST BANK: A COMPARATIVE STUDY
}

\author{
Sanjay Shrestha \\ Department of Finance, TU, Thakur Ram Multiple Campus, Birgunj, Nepal \\ Email:
}

\begin{abstract}
The study focuses on loan management of two commercial banks with reference of Nabil and Everest Bank of Nepal and its impact on profitability. This paper reports the comparative study of deposit, loan, ROA, ROE and CV. Descriptive research approach is applied for the readily available five years performance data from 201V 12 to 2015/16. Both of the banks have u lized most of the funds in the form of credit and advances which is the major part of utilizing deposits for income generating purpose. On the average, both Nabil and Everest bank have utilized its total deposits constant in consecutive years. Likewise, the mean ratio of total loan to total deposit of Nabil and Everest bank are $70.75 \%$ and 72.54\% respectively. By coefficient variation analysis, Everest bank has more uniformity than Nabil since Everest has less CV of 6.16\%. It can be concluded that the higher mean ratio indicates the good lending performance.
\end{abstract}

\section{Ke y words}

Deposit, loan; profitability, ROE; ROA

\section{Introduction}

Banking plays significant role in the economic development of the country. Bank is a resource for the economic development, which maintains the self-confidence of various segment of society and extends credit to the people. So, commercial banks are those financial institutions mainly dealing with activities of trade, industry and agriculture that seek regular financial and other helps from the growing and flourishing the objectives of commercial banks is to mobilize idle resources into the most profitable sector after collecting them from scattered sources. Commercial banks contribute significantly in the formation and mobilization of internal capital and development efforts.

Commercial banks are the heart of the financial system. They hold the deposits of individuals, government institutions and business units. They make funds available through their lending and investing activities to borrowers; individuals, business firms and government institutions. In doing so, they

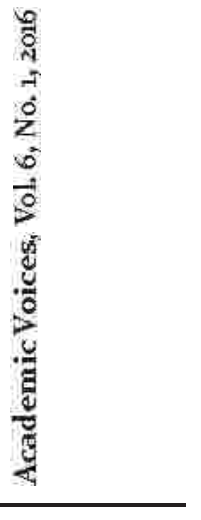


assist both the flow of goods and services from the producers to consumers and the financial activities of the government. They provide a large portion of medium of exchange and they are the media through which monetary policy is affected. These facts show that the commercial banking system of a nation is very important to the functioning of its economy (Van Horn, 2000).

Financial system contains two components depository financial and non-depository financial institutions. Commercial Banks and finance companies, in Nepalese context, are the examples of depository financial institution whereasEmployee Provident Fund, Insurance companies etc. are the examples of non-depository financial institution. All the economic activities are directly or indirectly channeled through these banks. People keep their surplus money as deposits in the banks and hence bank can provide such funds to finance the industrial activities in the form of loans and advances.

Management of bank risks is the most important factor for financial stability \&. economic growth in the developed economics (Roger, 2003). Management of tradeoff between risks \&returns is important for sustainable profitability of banks and other financial institutions. Among risk in banking operation credit risk which is related to substantial amount of income generating assets is found to be important determinants of bank performances. So, credit risk management capability of a bank remained a live managerial discourse in financial management \& overall health of financial institution depended upon the power management of credit risk. The risk focused examination process has been adapted to credit the inspection process to the more risk areas of both operation and business. Credit risk is considered as greater risk from all other risk affecting in the financial performance of bank.

\section{Methods}

Nabil Bank Ltd. and Everest Bank Ltd. were selected for the study of loan management. To conduct the study, five years data were taken from 2011/12 to 2015/16. To make the study more specific and reliable, two types of tools were used for analysis, The basic tools used were ratio analysis.

\section{Results and discussion}

\section{Total loans and advance to total deposit ratio}

Table 1shows that the total loan $\&$ adv. to total deposit ratio of Nabil are $74.79 \%, 72.90 \%$, $72.55 \%, 63.01 \%$ and $70.49 \%$ respectively from

Table r: Total loan and advance to total deposit (Rs.in million)

\begin{tabular}{|c|c|c|c|c|c|c|}
\hline \multirow[b]{2}{*}{ Fiscal Year } & \multicolumn{3}{|c|}{ Nabil } & \multicolumn{3}{|c|}{ Everest } \\
\hline & $\begin{array}{l}\text { Total Loan } \\
\text { and Advance }\end{array}$ & $\begin{array}{c}\text { Total De- } \\
\text { posit. }\end{array}$ & Ratio & $\begin{array}{l}\text { Total Loan } \\
\text { and Advance }\end{array}$ & $\begin{array}{c}\text { Total De- } \\
\text { posit }\end{array}$ & Ratio \\
\hline 2011 D & 41,065 & 54,905 & $74.79 \%$ & 35,910 & 50,006 & $7181 \%$ \\
\hline $2012 / 13$ & 46,369 & 63,609 & $72.90 \%$ & 43,393 & 57,720 & $75.18 \%$ \\
\hline $2013 / 14$ & 54,691 & 75,388 & $72.55 \%$ & 47,572 & 62,108 & $76.60 \%$ \\
\hline 2014/ 15 & 65,501 & 103,957 & $63.01 \%$ & 54,482 & 83,093 & $65.57 \%$ \\
\hline $2015 / 16$ & 77,730 & 110,267 & $70.49 \%$ & 68,911 & 93,735 & $73.52 \%$ \\
\hline Mean & & $70.75 \%$ & & & $72.54 \%$ & \\
\hline S.D & & 0.053 & & & 0.045 & \\
\hline C.V & & $7.34 \%$ & & & $6.16 \%$ & \\
\hline
\end{tabular}


fiscal year 2011/12 to 2015/16. Similarly, the ratios of Everest bank are $7181 \%, 75.18 \%$, $76.60 \%, 65.57 \%$ and $73.52 \%$ from fiscal year 2011 D to $2015 / 16$ respectively. Likewise, the mean ratio of Nabil and Everest are $70.75 \%$ and $72.54 \%$ respectively. Higher loan and advance to total deposit ratio shows higher risk and higher turnover. But, Nabil and Everest have invested their deposit more in loan and advance to earn constant profit. By coefficient variation analysis, Everest bank has more uniformity than Nabil since Everest has less CV of $6.16 \%$.

Nabil and Everest have been constant to mobilize its total deposit as loan and advances. Nevertheless, higher ratio doesn't necessarily mean that it is always better from profit point of view, because there may arise liquidity crisis. Both banks have equally aggressive. But it is true that the banks should aim to maintain more than $70 \%$ of deposits as loan to achieve profit.

\section{Loan loss provision to total loan and advances ratio}

Table 2 shows the loan loss provision to total loan $\&$ advance ratio of selected commercial banks over the five year study period. The ratio of Nabil is highest $3.07 \%$ in the fiscal year $2011 / 12$ and lowest $2.09 \%$ in the fiscal year $2015 / 16$. Average ratio of $\mathrm{Nabil}$ is $2.64 \%$. Likewise, this ratio of Everest is highest 196\% in the fiscal year $2011 / 12$ and lowest $1.39 \%$ in the fiscal year 2015/16. It has mean ratio of $173 \%$. Here, average Ioan loss provision to total Ioan ratio of Nabil is higher than Everest. This increased ratio indicates the increased volume of non-performing loans and vice versa. By measuring coefficient of variation, Nabil is less uniformity since it has higher CV of $10.10 \%$ than Everest i.e. $7.68 \%$.

The provision for loan loss reflects the increasing probability of non-performing loan. Increase in loan loss provision decreases its profit and result to decrease in dividends. But its positive impact is to strengthen the financial conditions of banks by controlling the credit risk and reduced the risks related to deposits. The low ratio indicates the good quality of assets in total volume of loan \&advances. High ratio indicates more risky assets in total volume of loan $\&$ advances.

\section{Non-performing loans to total loan and advances ratio}

Table 3 shows the non-performing loan to total loan over the five year study period. The ratio of $\mathrm{Nabil}$ ranges highest of $2.44 \%$ and the lowest is $114 \%$ in FY $2011 / 12$ and FY in 2015/16 respectively. Likewise, the ratio of

Table 2: Loan loss provision to loan and advance (Rs in millions)

\begin{tabular}{l|c|c|c|c|c|c} 
Fiscal Year & $\begin{array}{c}\text { Loan Loss } \\
\text { Provision }\end{array}$ & $\begin{array}{c}\text { Total Loan } \\
\text { and Advance }\end{array}$ & Ratio & $\begin{array}{c}\text { Loan Loss } \\
\text { Provision }\end{array}$ & $\begin{array}{c}\text { Total Loan } \\
\text { and Advance }\end{array}$ & $\begin{array}{c}\text { Ratio } \\
\text { 2011/ D }\end{array}$ \\
1,262 & 41,065 & $3.07 \%$ & 705 & 35,910 & $196 \%$ \\
\hline $2012 / 13$ & 1,275 & 46,369 & $2.75 \%$ & 804 & 43,393 & $185 \%$ \\
\hline $2013 / 14$ & 1,511 & 54,691 & $2.76 \%$ & 878 & 47,572 & $185 \%$ \\
\hline $2014 / 15$ & 1,659 & 65,501 & $2.53 \%$ & 881 & 54,482 & $162 \%$ \\
\hline $2015 / 16$ & 1,624 & 77,730 & $2.09 \%$ & 956 & 68,911 & $139 \%$ \\
\hline Mean & $2.64 \%$ & & & $173 \%$ & \\
\hline S.D & 0.0029 & & & 0.0014 & \\
\hline C.V & $10.10 \%$ & & & $7.68 \%$ & \\
\hline
\end{tabular}


Table 3: Non performing loans to total loan and advance ratio (Rs in millions)

\begin{tabular}{c|c|c|c|c|c|c} 
Fiscal Year & $\begin{array}{c}\text { Non-Per- } \\
\text { forming } \\
\text { Loan }\end{array}$ & $\begin{array}{c}\text { Total Loan } \\
\text { and Advance }\end{array}$ & Ratio & $\begin{array}{c}\text { Non-Per- } \\
\text { forming } \\
\text { Loan }\end{array}$ & $\begin{array}{c}\text { Total Loan } \\
\text { and Advance }\end{array}$ & Ratio \\
\hline 2011 D & 1,000 & 41,065 & $2.44 \%$ & 307 & 35,910 & $0.85 \%$ \\
\hline $2012 / 13$ & 1,015 & 46,369 & $2.19 \%$ & 276 & 43,393 & $0.64 \%$ \\
\hline $2013 / 14$ & 1,256 & 54,691 & $2.30 \%$ & 470 & 47,572 & $0.99 \%$ \\
\hline $2014 / 15$ & 1,220 & 65,501 & $186 \%$ & 367 & 54,482 & $0.67 \%$ \\
\hline $2015 / 16$ & 889 & 77,730 & $114 \%$ & 264 & 68,911 & $0.38 \%$ \\
\hline Mean & $199 \%$ & & & $0.71 \%$ & \\
\hline S.D & 0.0027 & & 0.0024 & \\
\hline C.V & $12.85 \%$ & & $34.68 \%$ & \\
\hline
\end{tabular}

Everest is highest of $0.99 \%$ and the lowest of $0.35 \%$ respectively in FY 2013/14 and 2010/11 The mean non-performing loan to total loan of Nabil and Everest are $199 \%$ and $0.71 \%$ respectively. Everest has the lowest nonperforming loan to total loan $\&$ advances, thus Everest is best performer than Nabil. However, the trend of NPL to total loan of Nabil is decreasing trend. By measuring coefficient of variation, Nabil is more uniformity since it has CV $12.85 \%$ than Everest with CV of $34.68 \%$.

Banking sector is seriously affected by the non-performing loans. Sample banks are not far from this above fact. If non-performing loan increases, the overall banking business will be affected. Therefore, provision amount will be increased and profit will decrease. Therefore, it is suggested that both thesam ple banks to be sincere while granting loan and to do effective follow up for recovery of nonperforming loans.

The Ratio of NPL to total loan Advance reveals how much or the loan and advances are nonperforming assets. It is calculated as follows.

Non-performing assets, also called nonperforming loans, are loans on which repayments or interest payments arenot being made on time. A loan is an asset for a bank as the interest payments and the repayments of the principal create a stream of cash flows. It is from the interest payments a bank makes its profits. Banks usually treat assets as nonperforming if they not serviced for some time. If payments are late for a short time a loan is classified as past due. Once a payment becomes really late the loan classified as nonperforming.

Increase in the amount of non-performing assets or loans means mismanagement of loan and deposit of individuals and households. Profitability of bank may dwindle. So commercial banks need to reduce nonperforming assets or loan.

\section{Loan loss provision (LLP) to performing loan}

Table 4presents the loan loss provision to performing loan ratio of Nabil and Everest during the last five fiscal years. The average LLP to ratio are $2.3 \%$ and $173 \%$ for Nabil and Everest respectively. Loan loss provision to the performing loan is directly related. As the performing loan increases LLP decreases. Although the ratio is fluctuating, it remained somewhat near $2 \%$. That means bank is trying to maintain the ratio constant at minimum. Likewise, Standard deviation for the Nabil and Everest are 0.0041 and $0.00 \mathrm{D}$ respectively. 
Table 4: Loan loss provision to performing loan (Rs. in millions)

\begin{tabular}{c|c|c|c|c|c|c} 
Fiscal Year & $\begin{array}{c}\text { Loan loss } \\
\text { Provision }\end{array}$ & $\begin{array}{c}\text { Performing } \\
\text { Loan }\end{array}$ & Ratio & $\begin{array}{c}\text { Loan loss } \\
\text { Provision }\end{array}$ & $\begin{array}{c}\text { Perforest } \\
\text { Loan }\end{array}$ & Ratio \\
\hline $2011 /$ D & 1,262 & 41,867 & $3.01 \%$ & 705 & 36,309 & $194 \%$ \\
\hline $2012 / 13$ & 1,275 & 46,630 & $2.18 \%$ & 804 & 43,921 & $183 \%$ \\
\hline $2013 / 14$ & 1,511 & 54,947 & $2.29 \%$ & 878 & 47,979 & $183 \%$ \\
\hline $2014 / 15$ & 1,659 & 63,473 & $192 \%$ & 881 & 53,659 & $164 \%$ \\
\hline $2015 / 16$ & 1,624 & 76,841 & $2.11 \%$ & 956 & 68,647 & $139 \%$ \\
\hline Mean & & $2.30 \%$ & & & $173 \%$ & \\
\hline S.D & 0.0041 & & & 0.0012 & \\
\hline C.V & $17.43 \%$ & & & $6.40 \%$ & \\
\hline
\end{tabular}

Coefficient of variation indicates the fluctuating trend or measuring the uniformity of the banks which is $17.43 \%$ and $6.40 \%$ for Nabil and Everest respectively. From the five years analysis i.e. fiscal year $2011 / 12$ to $2015 / 16$ LLP to LLP ratio is highest of Nabil which is 3.01\% than Everest i.e. 194\%. The analysis can be easily seen that the LLP to performing loan of Nabil is more fluctuating as compared to Everest.

Loan lossprovision is the compulsion factor in lending practices and Non-Performing Loan is the evil factor in banks. If they are high then they will decrease the amount of profit which is the bank's target to receive. This ratio measures the portion of provisioned loan with non-performing Loan.

\section{Profitability ratio}

Profit is an indispensable factor in any business organization. It is the amount of profit that may institution can make which decides its continuity in the future. For banking institution profit becomes a must because it has to cover different types of expenses on one hand and also make some payment in the form of dividends to their shareholders. It is the excess of income over expenditure. It is the key factor that measures how effectively the firm is being operated and managed.

\section{Ret urn on equity (ROE)}

Table 5 presents the result of return on equity of the sample banks. The average of this ratio is $28.21 \%$ and $25.63 \%$ for $\mathrm{N}$ abil and EBL respectively. This indicates that the return on equity for the bank is good i.e. Effectiveness of management in earning profit. Likewise, Standard deviation for the Nabil and Everest is 0.042 and $0.031 \%$ respectively. Coefficient of variation indicates the fluctuating frend or measuring the uniformity of the banks which is $14.55 \%$ and $1134 \%$ for $\mathrm{Nabil}$ and Everest respectively. From the five years analysis i.e. fiscal year $2011 / 12$ to $2015 / 16$ return on equity is higher of Nabil which is $28.21 \%$ than of EBL which is $25.63 \%$ in average among the two sample banks. According to the coefficient variation Everest is more uniformity which has less CV i.e. $\mathbf{1 1 3 4 \%}$ than Nabil.

ROE can be mathematically expressed as shown in table 5.

Return on equity measures the profitability of equity funds involved in the firm. $\mathrm{ROE}$ indicates how well the firm has used the resources of owners. It reveals the clear picture of the capacity of the bank to utilize its owner fund.

\section{Return on total assets (ROA)}

Table 6 shows the result of Net Profit to Total assets ratio or return on total assets of the sample banks. The average ratio for return on assets is $2.47 \%$ and $191 \%$ for Nabil and EBL respectively. This indicates that the return on assets for the bank is satisfactory. Likewise, 
Table 5: Return on Equity (Rs in millions)

\begin{tabular}{|c|c|c|c|c|c|c|}
\hline \multirow[t]{2}{*}{ Fiscal Year } & \multicolumn{3}{|c|}{ Nabil } & \multicolumn{3}{|c|}{ Everest. } \\
\hline & Net Profit & Total Equity & Ratio & Net Profit & Total Equity & Ratio \\
\hline 2011 D & 1,700 & 5,459 & $311 \%$ & 1,091 & 4,177 & $26.12 \%$ \\
\hline $2012 / 13$ & 2,219 & 6,691 & $33.16 \%$ & 1,471 & 4,827 & $30.47 \%$ \\
\hline $2013 / 14$ & 2,319 & 7,640 & $30.35 \%$ & 1,549 & 5,456 & $28.39 \%$ \\
\hline $2014 / 15$ & 2,098 & 9,518 & $22.04 \%$ & 1,574 & 6,889 & $22.85 \%$ \\
\hline $2015 / 16$ & 2,821 & 11,590 & $24.34 \%$ & 1,730 & 8,514 & $20.32 \%$ \\
\hline Mean & & $28.21 \%$ & & & $25.63 \%$ & \\
\hline S.D & & 0.042 & & & 0.031 & \\
\hline C.V & & $14.55 \%$ & & & $1134 \%$ & \\
\hline
\end{tabular}

Table 6: Return on total assets (Rs in millions)

\begin{tabular}{|c|c|c|c|c|c|c|}
\hline \multirow{2}{*}{ Fiscal Year } & \multicolumn{3}{|c|}{ Nabil } & \multicolumn{3}{|c|}{ Everest } \\
\hline & Net Profit & Total Asset & Ratio & Net Profit & Total Asset & Ratio \\
\hline 2011 D & 1,700 & 63,257 & $2.69 \%$ & 1,091 & 55,813 & $195 \%$ \\
\hline $2012 / 13$ & 2,219 & 73,241 & $3.03 \%$ & 1,471 & 64,741 & $2.27 \%$ \\
\hline $2013 / 14$ & 2,319 & 87,274 & $2.66 \%$ & 1,549 & 70,445 & $2.20 \%$ \\
\hline $2014 / 15$ & 2,098 & 118,695 & $177 \%$ & 1,574 & 99,167 & $159 \%$ \\
\hline $2015 / 16$ & 2,821 & 128,919 & $2.19 \%$ & 1,730 & 113,885 & $152 \%$ \\
\hline Mean & & $2.47 \%$ & & & $191 \%$ & \\
\hline S.D & & 0.0048 & & & 0.0027 & \\
\hline C.V & & $19.25 \%$ & & & 13.33\% & \\
\hline
\end{tabular}

Standard deviation for the Nabil and Everest are 0.0048 and 0.0027 respectively. Coefficient of variation indicates the fluctuating trend or measuring the uniformity of the banks which is $19.25 \%$ and $13.33 \%$ for Nabil and Everest respectively. From the five years analysis i.e. fiscal year $2011 / 12$ to $2015 / 16$ return on assets is higher of Nabil which is $2.48 \%$ than of EBL which is $2.03 \%$ among the two sample banks. In same way, financial surplus to assets ratio for sample banks are fluctuating trend. Nabil has more risky that is higher CV $19.25 \%$ than EBL of $13.33 \%$.

This ratio is related to net profit after tax (NPAT) and Total Assets. How efficiently is the assets of a firm able to generate more profit are measured by this ratio is calculated by dividing NPAT by Total Assets. This ratio provides the foundation necessary for a company to deliver a good return on equity. Return on Total Assets ratio of Standard Chartered Bank Nepal Ltd. and Nepal SBI
Bank Ltd. for the period of 2010/ 11 to 2014/ 15 .

\section{Coefficient of correlation}

The degree of the management success in handling the credits and advances of the bank is determined by the significance of a series of relationship of loans and advances among a number of factors such as net profit, liquid assets, total deposits etc. This relationship among different variables is determined by the Pearson's coefficient of correlation of the data of the respective banks. The objective behind this analysis is to understand and analyze the impact of the credit provided by the banks to its net profitability and liquidity position.

The coefficient of correlation measure the degree of relationship between two sets of figures. Among the various methods of finding out coefficient of correlation, Karl Pearson's method is applied in the study. 
Table 7: Correlation between de posit, loan and advance

\begin{tabular}{llllll|l}
\multicolumn{1}{c}{ Banks } & \multicolumn{1}{c}{$\mathbf{c}$} & \multicolumn{1}{c}{ r2 } & \multicolumn{1}{c}{ tcal } & \multicolumn{1}{c}{ ttab } & \multicolumn{1}{c}{ Result } \\
Nabil & 0.9907 & 0.981 & 12.73 & 3.182 & Significant \\
\hline Everest & 0.97 & 0.942 & 7.18 & 3.182 & Significant \\
\hline
\end{tabular}

\section{Correlation between deposit and loan and advance}

The relationship between the total loan and total deposit is of great significance as it indicates the direction taken by total loan with the changes in the volume of total deposit. A bank will be unable to provide large volumes of loan if it does not receive adequate and sufficient deposits in a timely basis. Table 7 shows the correlation coefficient between the total credit and total deposits denoted by $r$, $\mathrm{r} 2$ indicates the coefficient of determination, tcal and ttab refers to calculated value of t-statistic and tabulated value of t-statistic at $5 \%$ level of significance at 3 degree of freedom respectively.

Table 7 clearly highlights the relationship between the total Deposit received and loan and advance provided. The positive relationship shown by their correlation coefficient poin ts out the fact that the changes in each variable are taking place in the same direction, i.e., an increase in total loan is supported by an increase in the total deposit. This positive relationship is highly significant as the banks won't be able to sustain for a longer period if any one of these variables do not increase or decrease with oneanother. The calculated value tcal of both sample banks i.e. Nabil and Everest (12.73 and 7.18) is greater than tabulated value at $5 \%$ significance level with 3 degree of freedom for two tailed test (3.182). It indicates that there is significant difference between total loan and total deposit of $\mathrm{Nabil}$ and Everest.

\section{Correlation between loan and loan loss Provision}

The relationship between the total loan and loan loss provision indicates the volume of loss provision raised from the total credit granted. This suggests the volume and chances of loans being default or not paid by the clients are of significant value or not. Table 8 shows the correlation coefficient between the total credit and total nonperforming loans denoted byr. $\mathrm{r} 2$ indicates the coefficient of determination, tcal and ttab refers to calculated value of tstatistic and tabulated value of t-statistic at $5 \%$ level of significance at 3 degree of freedom respectively.

Table 8 presents the correlation coefficient between total loan and total loan loss provision of the Nabil and Everest. As depicted by the Table 8, the correlation between these two variables is highly positive of both Nabil and Everest bank, which means, they are moving in the same direction. Correlation between these two variables is positive, which means they are moving in the same direction. The positive relationship points out the fact that an increase in non-performing loans leads to an increase in total volume of loan. However, if the volume of loans being default decreases with the increase in the volume of loan provided, this denotes the effective handling of loans and efficient handling of nonperforming loans by the credit department. It also suggests that the staffs of the credit department have a quick learning curve when it comes to handing non-performing loans and credit.

Table 8: Correlation between loan and loan loss provision

\begin{tabular}{lllllll|}
\multicolumn{1}{c}{ Banks } & \multicolumn{1}{c}{$\boldsymbol{r}$} & \multicolumn{1}{c}{ [2 } & \multicolumn{2}{c}{ teal } & \multicolumn{1}{c}{ Result } \\
Nabil & 0.99 & 0.981 & 3.56 & 3.182 & Significant \\
\hline Everest & 0.979 & 0.9585 & 8.31 & 3.182 & Significant \\
\hline
\end{tabular}


The bank must keep a loan loss provision of pass loan (performing loan) which makes the positive relation in the variables. By using t- statistic, the calculated value tcalof both Nabil and Everest (3.56 and 8.31) is greater than tabulated ' $t$ ' at $5 \%$ significance level at 3 degree of freedom for two tailed test(3.182). It indicates that correlation coefficient between Ioan and advances and total nonperforming loan of Nabil and Everest is significant. It probably means that the volume of loan being default does significantly depend upon the volume of the loan provided only. There may be several other reasons for the loans being default.

\section{Conclusion}

Both of the banks have utilized most of the funds in the form of credit and advances which is the major part of utilizing deposits for income generating purpose. On the average, both Nabil and Everest bank have utilized its total deposits constant in consecutive years. Likewise, the mean ratio of total loan to total deposit of Nabil and Everest bank are $70.75 \%$ and $72.54 \%$ respectively. By coefficient variation analysis, Everest bank has more uniformity than Nabil since Everest has less $\mathrm{CV}$ of $6.16 \%$. It can be concluded that the higher mean ratio indicates the good lending performance.

The loan loss provision to loan and advance ratio of Nabil bank is highest than Everest bank. This increased ratio indicates the increased volume of non-performing loans and vice versa. The mean Non-performing Ioan to total Ioan of Nabil and Everest bank are $199 \%$ and $0.71 \%$ respectively. It has constant non-performing loan to total loan
\& advances of both banks. NPL to total loan of Nabil is decreasing trend over the study period, so this is good sign for the bank. By measuring coefficient of variation, Nabil is more fluctuating than Everest Bank.

The average ratio for return on assets is $2.47 \%$ and $191 \%$ for Nabil and Everest respectively. This indicates that the return on assets for the bank is satisfactory. Coefficient of variation indicates Nabil has more risky because it has higher CV than Everest. The average of return on equity of Nabil bank is higher than Everest. This indicates that this return for $\mathrm{Nabil}$ isgood i.e. effectiveness of management in earning profit to compare Everest. The high return is good sign of company growth and it is always positive for investment in such company for investor.

\section{References}

Bhattacharya, H. (1998). Banking Strategy, Credit Appraisal and Lending Decision: A Risk Return Framework. New Delhi: Ashoka Prakashan.

Bhandari, D. R. (2003). Principle and Practices of Banking \& Insurance. Kathmandu: Asmita Prakashan

Joshi, P. R. (2001). Research Methodology. Kathmandu: Buddha Academic Publishers and Distributors Pvt Ltd.

Kothari, C. R. (1990). Research Methodology: Methods and Techniques. 2nd Edition, New Delhi: Wishwa, Prakashan

Singh, H. B. (2005). Banking \& Insurance with Guidelines for Project Work \& Report Writing. New Delhi: Bikash Prakashan 